\title{
Optimal localisation of biofuel production on a European scale
}

\author{
Elisabeth Wetterlund, Sylvain Leduc, Erik Dotzauer and Georg Kindermann
}

\section{Linköping University Post Print}

N.B.: When citing this work, cite the original article.

Original Publication:

Elisabeth Wetterlund, Sylvain Leduc, Erik Dotzauer and Georg Kindermann, Optimal localisation of biofuel production on a European scale, 2012, Energy, (41), 1, 462-472.

http://dx.doi.org/10.1016/j.energy.2012.02.051

Copyright: Elsevier

http://www.elsevier.com/

Postprint available at: Linköping University Electronic Press

http://urn.kb.se/resolve?urn=urn:nbn:se:liu:diva-74574 


\title{
Optimal localisation of biofuel production on a European scale
}

\author{
Elisabeth Wetterlund ${ }^{\mathrm{a}, \mathrm{b}, *}$, Sylvain Leduc ${ }^{\mathrm{b}}$, Erik Dotzauer ${ }^{\mathrm{c}}$, Georg Kindermann ${ }^{\mathrm{b}}$ \\ ${ }^{a}$ Division of Energy Systems, Department of Management and Engineering, Linköping University, SE-581 83 Linköping, \\ Sweden \\ ${ }^{b}$ International Institute for Applied Systems Analysis (IIASA), Schlossplatz 1, Laxenburg A-2361, Austria \\ c Mälardalen University, P.O. Box 883, SE-721 23 Västerås, Sweden
}

\begin{abstract}
This paper presents the development and use of an optimisation model suitable for analysis of biofuel production scenarios in the EU, with the aim of examining second generation biofuel production. Two policy instruments are considered - targeted biofuel support and a $\mathrm{CO}_{2}$ cost. The results show that over 3\% of the total transport fuel demand can be met by second generation biofuels at a cost of approximately 65-73 EUR/MWh. With current energy prices, this demands biofuel support comparable to existing tax exemptions (around $30 \mathrm{EUR} / \mathrm{MWh}$ ), or a $\mathrm{CO}_{2}$ cost of around $60 \mathrm{EUR} / \mathrm{t}_{\mathrm{CO} 2}$. Parameters having large effect on biofuel production include feedstock availability, fossil fuel price and capital costs. It is concluded that in order to avoid suboptimal energy systems, heat and electricity applications should also be included when evaluating optimal bioenergy use. It is also concluded that while forceful policies promoting biofuels may lead to a high biofuel share at reasonable costs, this is not a certain path towards maximised $\mathrm{CO}_{2}$ emission mitigation. Policies aiming to promote the use of bioenergy thus need to be carefully designed in order to avoid conflicts between different parts of the EU targets for renewable energy and $\mathrm{CO}_{2}$ emission mitigation.
\end{abstract}

Keywords: Biofuels; Bioenergy; Energy system optimisation; Energy policy; $\mathrm{CO}_{2}$ emissions

\section{Introduction}

With the aim of mitigating $\mathrm{CO}_{2}$ emissions, diversifying the energy supply and reducing dependence on imported fossil fuels, the European Union (EU) has set ambitious targets for a transition to renewable energy. The integrated energy and climate change policy adopted in 2008 defines general targets of $20 \%$ greenhouse gas reduction, $20 \%$ reduced energy use through increased energy efficiency and a $20 \%$ share of renewable energy by 2020 [1]. Increased production and use of bioenergy is promoted as a key to reaching the targets [2], as biomass can replace fossil fuels in stationary applications, such as heat or electricity production, as well as in the transport sector. In order to explicitly stimulate a shift to renewables in transportation, the European Commission has, in addition to the overall $20 \%$ renewable energy target, set a mandatory target of $10 \%$ renewable energy in transport by 2020 [3], with a transitional target of 5.75\% for 2010 [4]. Today the total annual energy use in road transport is approximately 3,600 TWh [5]. Of this less than $4.7 \%$ consists of renewable energy [6], which is well short of even the 2010 goal.

A number of policy instruments that directly or indirectly affect the production and use of biofuels are today in place in the EU (see e.g. [7, 8]). Targeted biofuel policies such as exemption from or reduction of transport fuel taxes, quotas and blend obligations have a direct effect on the competitiveness and market shares of biofuels. Policy instruments that do not directly target the transport sector, for example tradable $\mathrm{CO}_{2}$ emission permits and policies targeting renewable electricity production, can also affect biofuel production by stimulating the demand for bioenergy with potentially increased prices as a result.

The last few years have seen an increase in criticism of biofuels, especially regarding first generation biofuels, i.e., biofuels that are commercially available today and that in general use agricultural feedstocks. The criticism is to a large extent related to issues regarding competition with food production and potential negative environmental impact from biofuel production, in particular associated with effects from land use change $[9,10]$. Second generation biofuels are biofuels using lignocellulosic feedstock; for example gasification-derived fuels such as methanol, Fischer-Tropsch diesel (FTD) or dimethyl ether (DME), or lignocellulosic ethanol. In general second generation biofuels have lower specific land use requirements than first generation fuels, and since they are based

\footnotetext{
* Corresponding author. Tel. +46 13 284075; fax: +4613281788.

E-mail address: elisabeth.wetterlund@liu.se
} 
on non-food feedstocks, such as various types of waste and forest residues, the competition with food production is considerably lower. Although these biofuels are not yet commercially available much hope is currently placed on them. Studies show that it will likely be necessary to have a significant share of second generation fuels in the EU fuel mix, around 3\% of the total transport energy demand, in order to reach the biofuel target for 2020 without substantial interference with other goals (see e.g. $[11,12])$.

Second generation biofuel production plants will likely need to be large to reach necessary efficiencies and economies of scale, as discussed for example by Faaij [13]. Large plant sizes increase the necessary feedstock supply area and put significant demands on the supply chain, which makes it necessary to carefully choose the geographic location of the production plants with respect to fuel demand and feedstock locations. Since the potential for biomass is limited, efficient utilisation is necessary. Co-production of several energy carriers as a means to reach increased system efficiency is promoted in the EU cogeneration directive for simultaneous production of electricity and heat [14]. Cogeneration can also be an option for second generation biofuel production, where a considerable part of the feedstock energy not converted into biofuel can be recovered as other energy products, such as heat, electricity, lignin or biogas (see e.g. [15-19]). Co-production thus gives an opportunity for higher total conversion efficiencies, but also puts additional requirements on the determination of the optimal biofuel production plant locations.

This paper presents the development and use of a spatially explicit optimisation model suitable for extensive analysis of biofuel production scenarios in the EU, with the aim of determining and investigating advantageous locations for production of second generation biofuels. The main focus is on assessing how different parameters affect second generation biofuel production regarding costs, plant locations, production volumes and the possibility of reducing global fossil $\mathrm{CO}_{2}$ emissions. Key parameters to be studied are economic policy instruments affecting biofuel production, such as targeted biofuel support and the cost for emitting $\mathrm{CO}_{2}$, energy prices, heat delivery opportunities, feedstock costs and availability, and capital costs. The abovementioned 3\% share of second generation biofuels for meeting the 2020 target is used as a starting point, with the analysis focusing on boundary conditions that affect the possibility of meeting this goal.

\section{$2 \quad$ Methodology and input data}

The optimisation model is used to determine the location and size of biofuel production plants, given the locations of feedstock and energy demand. The model minimises the costs of the complete biofuel supply chain of the studied system, including biomass harvest, biomass transportation, conversion to biofuel, transportation and delivery of biofuel, and sales of excess heat and electricity. Fossil $\mathrm{CO}_{2}$ emissions are also considered, by including a cost for emitting $\mathrm{CO}_{2}$, such as a tax or tradable emission permits.

\subsection{Model description}

The model used in this study is based on the established geographically explicit bioenergy conversion optimisation model BeWhere, which has previously been used in studies of smaller regions or countries, incorporating different biofuel production technologies as well as other bioenergy conversion technologies, such as combined heat and power (CHP) (see e.g. [17, 20-23]). For this study, the model has been further developed to encompass biofuel production in the EU. The BeWhere model has been described in detail by Leduc [24] and Wetterlund [25].

The optimisation model is based on mixed integer linear programming (MILP). It has been developed in the commercial software GAMS [26] and is solved using CPLEX. In order to reduce calculation times, the EU has been divided into eight regions delimited by natural boundaries (water, mountains), which are in turn divided into grid cells with a half-degree spatial resolution (approximately $50 \times$ $50 \mathrm{~km}$ ). Within each region, the distances between all grid points are computed, in order to be able to calculate transportation costs between any two points. Interchange of biomass feedstock or biofuel between the regions can only take place at defined trade points, situated at major harbour locations or 
strategically located border points. Feedstock and biofuel can be traded from one harbour to any other harbour, whereas inland trades can only occur at one specific inland trade point. The trades between the regions are based on the transportation costs of the commodities. No trade taxes are applied between regions or countries.

Figure 1 shows the eight regions with the included trade points. Countries not belonging to the EU (hatched areas) are not considered with respect to energy demand or biomass supply, but trade is allowed through those countries. Malta and Cyprus, both island nations with relatively small populations, have been excluded from the EU for this study.

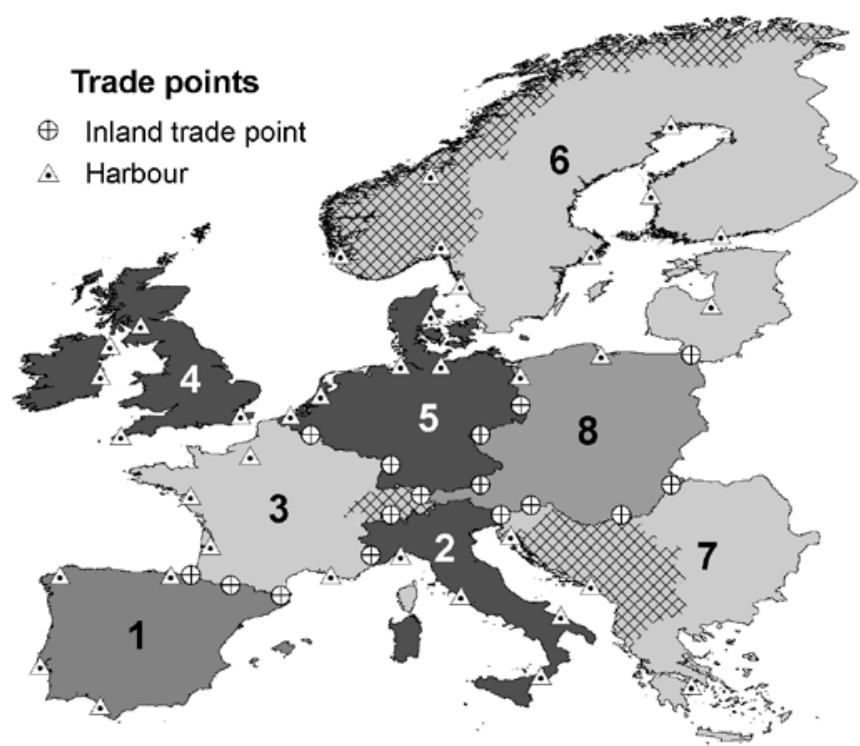

Figure 1. Region definition and location of the trade points. Hatched areas are non-EU countries and not included in the study.

The model minimises the total $\operatorname{cost} C_{\text {tot }}$ of the supply chain, which is defined as

$C_{\text {tot }}=C_{\text {supplychain }}+E_{\text {supplychain }} C_{C O 2}$

where $C_{\text {supplychain }}$ is the supply chain cost, $E_{\text {supplychain }}$ the supply chain emissions, and $C_{\mathrm{CO} 2}$ the cost for emitting $\mathrm{CO}_{2}$.

The supply chain cost $C_{\text {supplychain }}$ includes:

- feedstock cost, collection cost and transportation cost to the production plant,

- production plant: set-up and biofuel production costs,

- biofuel transport cost to gas stations,

- income from co-products (i.e., heat, power),

- feedstock/biofuel transportation from one region to another,

- fossil fuel cost for transport.

The supply chain emissions $E_{\text {supplychain }}$ include:

- emissions of fossil $\mathrm{CO}_{2}$ from feedstock and biofuel transportation,

- emissions from additional transport fossil fuel use,

- offset emissions from replaced fossil transportation fuel, electricity and heat.

The supply chain cost is minimised subject to a number of constraints regarding for example biomass supply, biomass/biofuel trade balance, production plant operation balance, and energy demand. For the full mathematic problem formulation, see Leduc [24] and Wetterlund [25]. 
When running the model, the least costly pathways are selected, from one set of feedstock supply points to a specific production plant, and further to a set of biofuel demand points. The resulting output from the model consists of the location of a set of plants, the different trade flows of feedstock and biofuel between regions, and the cost and $\mathrm{CO}_{2}$ emissions of the supply chain.

\subsection{Biofuel supply chain}

\subsubsection{Biomass supply}

A number of different cellulosic feedstocks could be used for the production of second generation biofuels, for example various woody materials, grasses and agricultural residues. This study only considers forest residues. The average potential supply of forest biomass for use in biofuel production is calculated using the current forest cover, and a yield estimate. The forest cover map has been derived from the global land cover map 2000 [27]. The yield has been derived by using the net primary productivity map from Cramer [28], and linking the net productivity with forest growth functions, which are calibrated using forest increments observed by national forest inventories. The central growth function has the form of

$T C P_{t}=T C P_{\max } e^{k \ln ^{2}\left(t / t_{\max }\right)}$

and estimates the total carbon production (TCP), until a stand age $t$, by using the form factor $k$ and the maximum total carbon production $\left(T C P_{\max }\right)$, which will be reached at the stand age $t_{\max }$. By combining the forest cover map with a biomass map [29], the yield estimates, and the growth function, it is possible to estimate the current age distribution. For estimating the sustainable average harvest potentials, the rotation time, where the average increment will culminate, is selected, and the age distribution of the age classes, until the rotation times are equally distributed. This allows an estimation of the sustainable potential wood increment and harvests for each grid cell. It is assumed that $20 \%$ of the total annual wood increment, representing forest residues such as branches, low quality wood or tops from final felling, is available for biofuel production. No distinction is made between different tree species. Figure 2 shows the distribution of forest biomass resources available for biofuel production.

The calculated forest biomass production cost includes cost of felling and forwarding to the forest road, and depends on population density, forest share, land cost level and slope [23], with an average cost in the EU of $17 \mathrm{EUR} / \mathrm{MWh}$. When adding transport costs, this is comparable to current European market prices of forest biomass [30, 31].

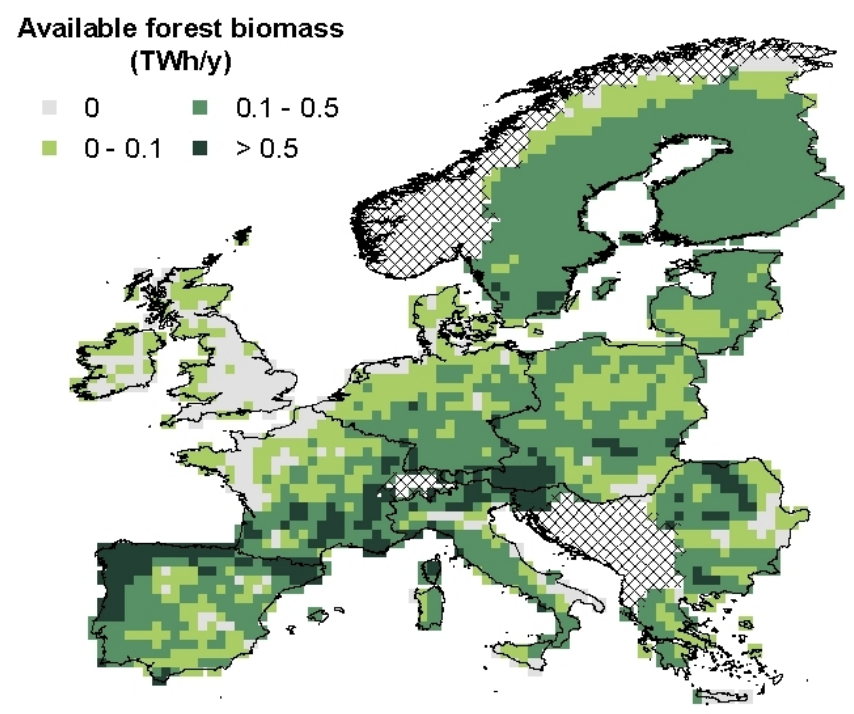

Figure 2. Amounts of forest biomass available for biofuel production (TWh/y). Hatched areas are non-EU countries and not included in the study. 


\subsubsection{Biofuel production}

Production of second generation biofuels is still in the development stage, with several different process concepts being investigated for each biofuel production route. In this study, two different biofuel technologies are considered: methanol via gasification and cellulosic ethanol via hydrolysis and fermentation. Electricity and/or heat are co-produced. Surplus heat can either be sold as district heating or, if no heat demand exists close to the plant location, be wasted. Excess electricity is sold to the grid.

For methanol a production process described by Hamelinck and Faaij [32] is considered. In the process, biomass is gasified in an atmospheric indirectly heated gasifier, followed by steam reforming and liquid phase methanol synthesis. Electricity is co-produced in a steam cycle in sufficient quantities to cover the process demands, but with no surplus for export. The potential to recover excess process heat for use as district heating is estimated from data in [33].

For ethanol, the process considered is based on $\mathrm{SO}_{2}$-catalysed steam pretreatment followed by simultaneous saccharification and fermentation, as described by Barta et al. [34]. Biogas is produced from the wastewater via anaerobic digestion, and incinerated together with the solid waste fractions for production of steam and electricity. Condensation heat is recovered and exported as district heating.

An annual operating time of 8,000 hours is assumed for both technologies. Scale effects have a strong impact on the costs of biomass conversion systems, as discussed by e.g. Dornburg and Faaij [35] and Sørensen [36]. Investments costs are scaled using the general relationship

$$
\frac{\text { Cost }}{\text { Cost }_{\text {base }}}=\left(\frac{\text { Size }}{\text { Size }_{\text {base }}}\right)^{R}
$$

where Cost and Size represent the investment cost and plant capacity respectively for the new plant, Cost $_{\text {base }}$ the known investment cost for a certain plant capacity Size $_{\text {base }}$, and $R$ is the scaling factor. An overall scaling factor of 0.7, the average value for chemical process plants [37], is used. Process efficiencies are assumed constant over the entire scale range. The size range is set to 25-100 $t_{\text {biomass }} / \mathrm{h}$, which corresponds to approximately 110-450 $\mathrm{MW}_{\text {biomass }}$.

Investment costs for new plants are annualised using an assumed economical lifetime of 20 years and an interest rate of $10 \%$, giving a capital recovery factor of 0.11 . Table 1 summarises key input data for the technologies.

Table 1. Key input data for the biofuel production technologies. Investment costs have been adjusted to EUR $_{2009}$ using the Chemical Engineering Plant Cost Index [38].

\begin{tabular}{|c|c|c|c|}
\hline Parameter & Unit & Methanol $^{\mathrm{a}}$ & Ethanol $^{\mathrm{b}}$ \\
\hline Base plant capacity & MW & 357 & 105 \\
\hline Base investment cost & MEUR & 505 & 143 \\
\hline Operation and maintenance (O\&M) cost & $E U R / M W h_{\text {biomass }}$ & 4.4 & 8.9 \\
\hline Biofuel efficiency & $\mathrm{MWh}_{\text {biofuel }} / \mathrm{MWh}_{\text {biomass }}$ & 0.55 & 0.30 \\
\hline Electrical efficiency & $\mathrm{MWh}_{\text {electricity }} / \mathrm{MWh}_{\text {biomass }}$ & 0 & 0.11 \\
\hline District heating efficiency & $\mathrm{MWh}_{\text {heat }} / \mathrm{MWh}_{\text {biomass }}$ & 0.11 & 0.40 \\
\hline
\end{tabular}

\subsubsection{Transportation and distribution}

A network map of roads, rails and shipping routes is used to calculate transportation routes and distances $d$ between supply areas and production plants, as well as between production plants and demand areas. This has been described in detail by Leduc et al. [23, 24]. Three transportation means for biomass feedstock and produced biofuels are included: truck, train and boat. The resulting transportation routes can consist of any combination of the three transportation means. 
Transport costs for logging residues and biofuel reported by Börjesson and Gustavsson [39] are used as base costs. Since Börjesson and Gustavsson report transport costs in USD/TJ, heating values and moisture contents of feedstocks and biofuels are used to estimate the transport costs for other energy carriers. The transport costs are also adjusted to account for currency development. The resulting transport costs are presented in Table 2.

All gas stations are assumed to be able to handle biofuel distribution, after certain alterations to the existing equipment. The dispensing costs for the two biofuels are assumed equal, at $0.86 \mathrm{EUR} / \mathrm{MWh}$ [24].

Table 2. Transport costs in EUR/MWh for feedstock and biofuels, where $d$ is the transport distance in $\mathrm{km}$. Adapted from [39].

\begin{tabular}{lccc}
\hline Energy carrier $^{\mathbf{a}}$ & Truck & Train & Boat \\
\hline Forest residues & $1100+24.9 d$ & $2330+3.47 d$ & $2680+1.42 d$ \\
Methanol & $441+9.77 d$ & $1360+2.11 d$ & $1480+0.473 d$ \\
Ethanol & $328+7.26 d$ & $1010+1.57 d$ & $1100+0.351 d$ \\
\hline
\end{tabular}

${ }^{\mathrm{a}}$ Forest residues are assumed to have a heating value of $5.13 \mathrm{MWh} / \mathrm{t}$ (LHV, dry feedstock) and a moisture content of 50\%. Heating value of methanol is $5.52 \mathrm{MWh} / \mathrm{t}$, and of ethanol 7.44 MWh/t [40].

\subsection{Energy demand}

\subsubsection{Transport fuel demand}

The total energy demand in road transport in the EU is currently around 3,600 TWh/y, with an estimated increase to over $4,000 \mathrm{TWh} / \mathrm{y}$ in 2020 [5, 41]. If the entire available quantity of forest residues presented in Section 2.2.1 was to be used for production of second generation biofuels, 3-6\% of the total transport fuel demand in 2020 could be covered, depending on biofuel conversion technology.

In this study, the projected transport fuel demand and population for 2020 are used as basis [41]. The national demand (given in Table A.1 in Appendix A) is downscaled based on grid point population [42], with the demand per capita assumed equal in all grid points of each country. Figure 3 shows the spatial distribution of transport fuel demand. When executing the optimisation model, any fuel demand not met by biofuel is covered by fossil transport fuels.

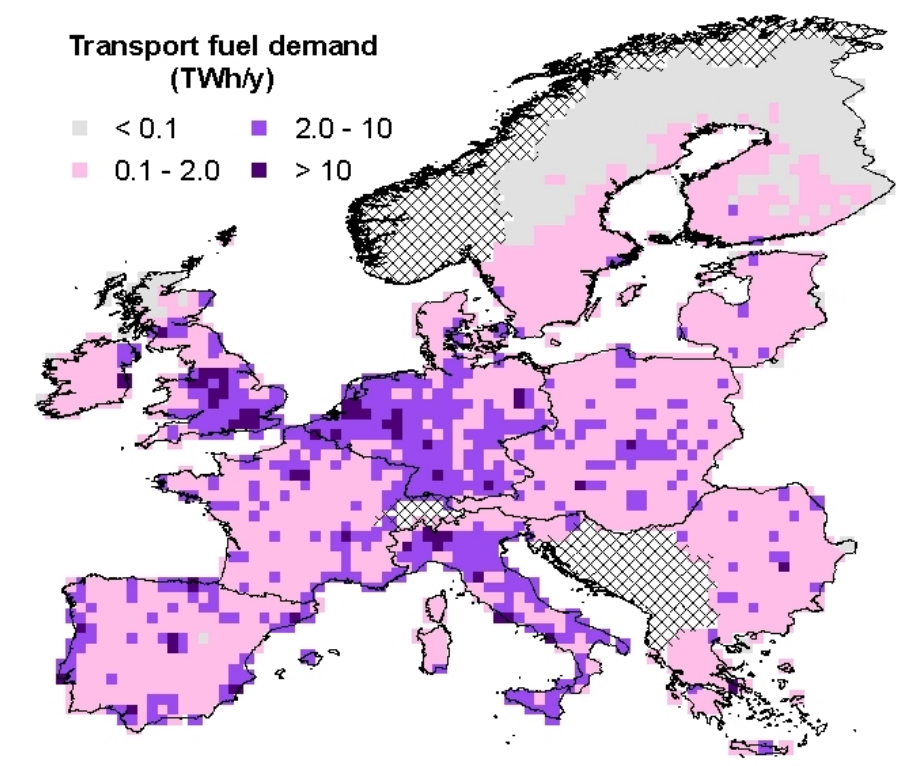

Figure 3. Transport fuel demand (TWh/y) [41]. Hatched areas are non-EU countries and not included in the study. 


\subsubsection{District heating demand}

Data on district heating in the EU has been obtained from Werner [43] and Egeskog et al. [44]. No data on individual district heating systems has been collected. Instead the total national district heating demand has been downscaled under the assumption that the district heating demand is proportional to the population of each grid point. The heat that could be replaced by the heat from biofuel production depends on a number of highly system-specific factors, such as heat load, current production mix and age structure of the existing heat production plants. Here the district heating systems are described on a nationally aggregated level, with the heat delivered from the biofuel production plants assumed to displace heat corresponding to a heat mix specific to each country. As discussed by Knutsson et al. [45], analysis on an aggregated level can be acceptable when the main focus is not to describe detailed impact on the district heating sector, as this approach significantly reduces the data collection burden. Since the aim of this study is to give a broad view of the potential in EU for domestic biofuel production, an aggregated approach was considered sufficient.

It is assumed that all existing fossil heat, from CHP plants as well as from heat-only boilers, can be replaced by heat from the biofuel production plants. As shown by Werner [43], there is a substantial potential for expansion of the European district heating systems, by replacing fossil fuels used for heating. In total a doubling of the current district heating load could be achieved by 2020. Here this entire expansion potential is also assumed available as a heat sink for heat from the biofuel production plants. A simplified heat load duration curve is applied, with the year divided into three seasons of equal length. To accommodate for variance in annual load distribution at different latitudes, three different load profiles are used, of which one represents the northern EU countries, one represents the central, and one represents the southern countries.

The heat distribution distance limit is set to $50 \mathrm{~km}$. Costs for investments in district heating equipment, such as pipes, pumps or heat exchangers are not included.

Figure 4 shows the distribution of the available heat load, with Table A.1 in Appendix A summarising the national heat loads. For more details, see [25].

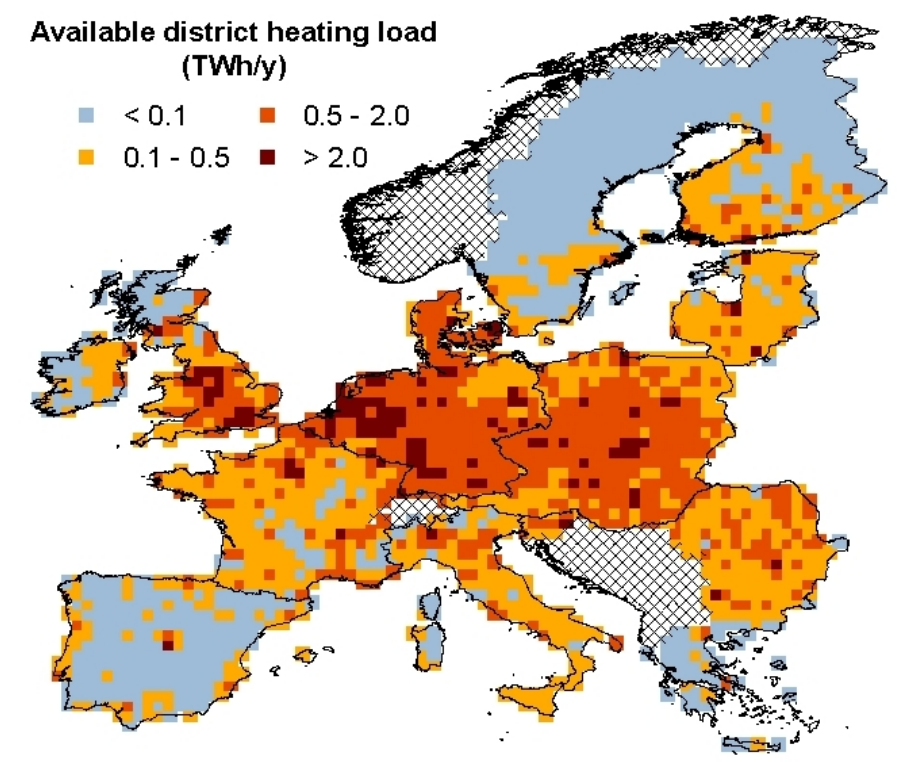

Figure 4. Available district heating load (TWh/y) [43, 44]. Hatched areas are non-EU countries and not included in the study. 


\section{$2.4 \mathrm{CO}_{2}$ emissions}

The cost of emitting fossil $\mathrm{CO}_{2}$ is internalised in the model, by including the possibility to apply a $\mathrm{CO}_{2}$ cost to the supply chain emissions. The cost could for example be a $\mathrm{CO}_{2}$ tax or tradable emission permits. Emissions from transportation of feedstock and biofuels, as well as emissions from displaced fossil energy carriers, are considered.

Produced biofuel is assumed to replace fossil transportation fuels at a 1:1 energy ratio. Thus each MWh of produced biofuel displaces $282 \mathrm{~kg}$ of $\mathrm{CO}_{2}$ [46]. Potential country-specific differences in $\mathrm{CO}_{2}$ emissions from transport fuels are not considered. Concerning heat, all fossil district heating, as well as the share of the fossil fuel-based heat that could be replaced by district heating, is considered. Thus, heat delivered from the biofuel production plants is assumed to displace heat corresponding to country-specific fossil fuel heat mixes. The $\mathrm{CO}_{2}$ emission factors range from $254-425 \mathrm{~kg}_{\mathrm{CO} 2} / \mathrm{MWh}$, with high emission factors for countries with a high share of coal based heat, and low for countries with more natural gas in the heat mix. Country-specific $\mathrm{CO}_{2}$ emission factors for heat are given in Table A.1 in Appendix A.

For electricity it is assumed that a net surplus of electricity affects the marginal electricity production. The EU electricity market has been deregulated since 2007, with the explicit ambition of the European Commission to overcome remaining obstacles to a fully integrated electricity market, such as transmission capacity bottlenecks [47, 48]. For this reason, a uniform marginal electricity production is assumed for the entire $\mathrm{EU}$, in the form of coal power with a $\mathrm{CO}_{2}$ emission factor of $723 \mathrm{~kg} \mathrm{CO}_{2} / \mathrm{MWh}$ [49].

$\mathrm{CO}_{2}$ emissions from the combustion of biomass are not considered, as it is assumed that the $\mathrm{CO}_{2}$ released when combusting the biomass is balanced by $\mathrm{CO}_{2}$ uptake in re-growing trees. Marginal effects of drastically increased exploitation of biomass resources could also be included, as this can have significant impact (see e.g. [50]). This is however not included at this stage of model development.

Emissions related to transportation of biomass feedstock and biofuels are given in Table 3.

Table 3. $\mathrm{CO}_{2}$ emissions from transportation in $\mathrm{g}_{\mathrm{CO} 2} / \mathrm{km} / \mathrm{MWh}$ of feedstock and biofuels [51].

\begin{tabular}{lccc}
\hline Energy carrier $^{\mathbf{a}}$ & Truck & Train & Boat \\
\hline Forest residues & 18.9 & 9.62 & 4.95 \\
Methanol & 8.77 & 4.47 & 2.30 \\
Ethanol & 6.51 & 3.32 & 1.71 \\
\hline
\end{tabular}

${ }^{\mathrm{a}}$ Emission factors calculated assuming a heating value of $5.13 \mathrm{MWh} / \mathrm{t}$ (LHV, dry feedstock) and a moisture content of $50 \%$ for forest residues. Heating value of methanol is $5.52 \mathrm{MWh} / \mathrm{t}$, and of ethanol 7.44 MWh/t [40].

\subsection{Energy prices}

The energy prices assumed in this kind of study will naturally affect the results to a large extent. Today the energy prices in the different EU member states are highly diversified. Since it is very difficult to predict future prices in all the EU states, country-specific energy prices for 2009 are used in this study, with sensitivity analysis of various energy price parameters being performed.

For transport fuel, average petrol and diesel pump prices (without taxes) from 2009 are used [52]. District heating prices are estimated consumer price averages for 2003 [43], adjusted to EUR 2009 . It is assumed possible to sell heat at $50 \%$ of the consumer buying price. Electricity prices are average enduser prices without taxes from 2009 [53]. Table A.1 in Appendix A shows the country-specific energy prices used. 


\subsection{Scenarios}

Three base scenarios are created, based on different applied policy support. In the first group of scenarios (A), no policy support is included. In the A base scenario (A0), the input data described in Sections 2.2-2.5 is utilised.

In the second group of scenarios (B), a cost for emitting fossil $\mathrm{CO}_{2}$ is applied. The model is first executed with increasing $\mathrm{CO}_{2}$ cost in order to estimate what approximate level of $\mathrm{CO}_{2}$ cost would be needed to meet the $3 \%$ second generation biofuel target mentioned in the introduction. This cost is then applied in the B scenarios.

In the third group of scenarios (C), targeted biofuel support is applied, representing for example a feed-in tariff or a reduction in or exemption from transport fuel taxes. Similarly as with the $\mathrm{CO}_{2}$ cost, the model is executed with increasing level of policy support, in order to find a level which yields a $3 \%$ share of second generation biofuels in the EU fuel mix, after which this level is applied in the C scenarios.

For each of the three base scenarios (A0, B0 and C0), parameter variation is performed. Energy prices, heat delivery opportunities, feedstock costs and availability, and plant costs are included in the analysis. In total, 12 different parameter variations are performed, with one parameter varied at a time. The same parameter variation is conducted for each of the three base scenarios, resulting in three groups of scenarios: A1-A12, B1-B12 and C1-C12.

In scenarios 1-2, the price of the biomass feedstock is varied (decreased or increased by 25\%), while in scenario 3 it is assumed that only $5 \%$ of the annual wood increment is available for biofuel production, representing for example a case with strong competition from other sectors. In scenarios 4-5, the price of fossil transport fuel is varied (decreased or increased by 25\%). Correspondingly, in scenarios 6-7, the electricity price is decreased or increased by $25 \%$, and in scenarios $8-9$, the district heating price is varied in the same way. In scenario 10 the possibility to sell heat as district heating is removed completely. Scenarios 11-12 concern the high uncertainty related to production plant costs. In scenario 11 , the investment cost of all new production plant types is increased by $25 \%$. Finally, scenario 12 regards the uncertainty introduced by using investment input data from different studies, by applying uniform investment and operation and maintenance (O\&M) costs for both biofuel production technologies. Table 4 summarises the parameter variation.

Table 4. Parameter variation scenarios for each group of scenarios, where the A scenarios contain no policy support, the $\mathrm{B}$ scenarios apply a $\mathrm{CO}_{2}$ cost, and the $\mathrm{C}$ scenarios apply biofuel support. Bold text represents parameters changed compared to the base scenarios. The scenarios are described more in detail in the text above.

\begin{tabular}{cccccc}
\hline $\begin{array}{c}\text { Scenario } \\
\mathbf{A} / \mathbf{B} / \mathbf{C}\end{array}$ & $\begin{array}{c}\text { Biomass } \\
\text { feedstock }\end{array}$ & $\begin{array}{c}\text { Fossil } \\
\text { transport fuel }\end{array}$ & Electricity & Heat & Production plant costs \\
\hline 0 & base & base & base & base & base \\
\hline 1 & Price $-\mathbf{2 5 \%}$ & base & base & base & base \\
2 & Price $+\mathbf{2 5 \%}$ & base & base & base & base \\
3 & Availability $-\mathbf{7 5 \%}$ & base & base & base & base \\
\hline 4 & base & Price $-\mathbf{2 5 \%}$ & base & base & base \\
5 & base & Price $+\mathbf{2 5 \%}$ & base & base & base \\
\hline 6 & base & base & Price $-\mathbf{2 5 \%}$ & base & base \\
7 & base & base & Price $+\mathbf{2 5 \%}$ & base & base \\
\hline 8 & base & base & base & Price $-\mathbf{2 5 \%}$ & base \\
9 & base & base & base & Price $+\mathbf{2 5 \%}$ & base \\
10 & base & base & base & No heat demand & base \\
\hline 11 & base & base & base & base & Inv. cost + 25\% \\
12 & base & base & base & base & Inv. + O\&M costs harmonised \\
\hline
\end{tabular}




\section{Results}

As has been described, the model takes the entire supply chain into account, from feedstock to end energy users. In cases where the use of biofuels is more economical than fossil transport fuels, biofuel production plants will be included in the solution, using the least costly pathways from supply to demand. The resulting output from the model consists of the location of a set of plants, biofuel production characteristics, the different trade flows of feedstock and biofuel between regions, and the costs and $\mathrm{CO}_{2}$ emissions of the supply chain.

The first of the following sections outlines the results regarding the necessary policy support levels in order to reach a 3\% second generation biofuel share in the EU, which are then used in the subsequent model runs and analyses. The following sections present and discuss the results regarding biofuel supply costs, biofuel shares, optimal plant locations, trade, and $\mathrm{CO}_{2}$ emissions.

\subsection{Policy support needed to reach $3 \%$ second generation biofuels}

Figure 5 shows the resulting share of second generation biofuels in the EU transport fuel mix for increasing levels of the two considered support policy instruments; $\mathrm{CO}_{2}$ cost and targeted biofuel support.

The $\mathrm{CO}_{2}$ cost needed to reach $3 \%$ second generation biofuels is found to be $59 \mathrm{EUR} / \mathrm{t}_{\mathrm{CO} 2}$, which is used as a basis for the continued analysis (B scenarios). This can be compared to the trading price of emission allowances within the European Union Emission Trading Scheme (EU ETS), which during the last five years has varied from under 10 to over $30 \mathrm{EUR} / \mathrm{t}_{\mathrm{CO} 2}$, with a price of around $15 \mathrm{EUR} / \mathrm{t}_{\mathrm{CO} 2}$ during most of 2009-2011 [54]. Comparison to estimates of the actual marginal costs attributed to $\mathrm{CO}_{2}$ emissions is difficult, as those estimates are highly diversified, ranging from next to nothing to over $100 \mathrm{EUR} / \mathrm{t}_{\mathrm{CO} 2}$ (see e.g. [55, 56]).

The figure also shows that the biofuel support level needed to reach the $3 \%$ goal is $31 \mathrm{EUR} / \mathrm{MWh}$ biofuel, which is used subsequently in this study (C scenarios). This can be compared to the average tax exemption in the EU which today amounts to $26 \mathrm{EUR} / \mathrm{MWh}$ for biodiesel and $48 \mathrm{EUR} / \mathrm{MWh}$ for ethanol, with an average value of $30 \mathrm{EUR} / \mathrm{MWh}$ [57].

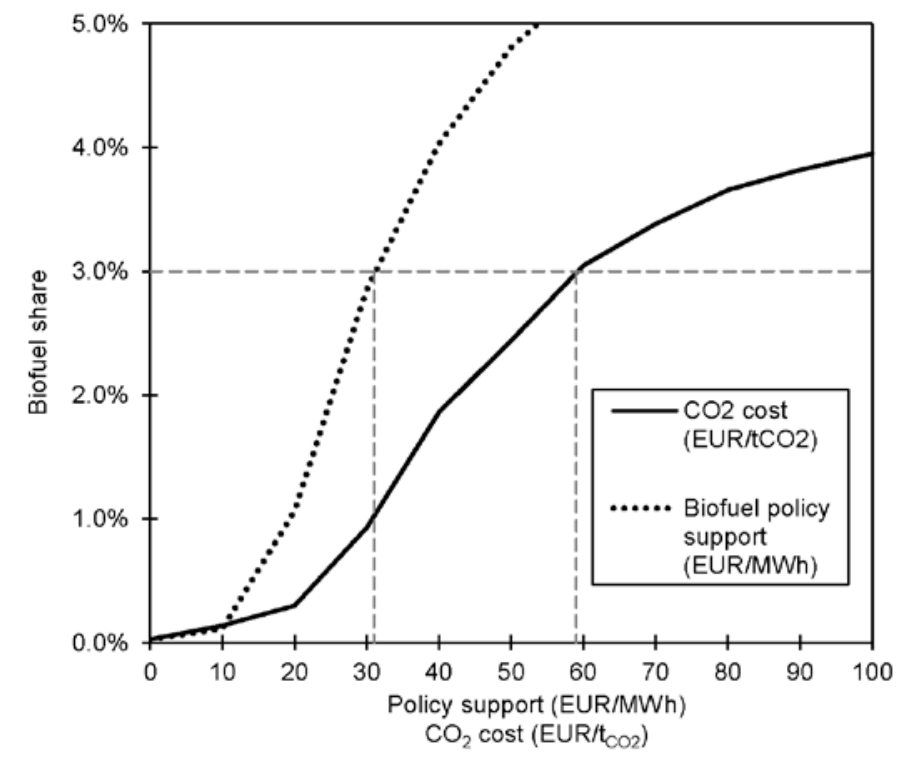

Figure 5. Second generation biofuel share in the EU for increasing levels of $\mathrm{CO}_{2}$ cost and biofuel policy support. The $3 \%$ target has been marked. 


\subsection{Biofuel supply costs and biofuel share}

Since the model minimises the entire system cost, any given demand point can be supplied by either locally produced biofuel, biofuel transported from another production location, or fossil transport fuels, depending on which provides the lowest supply cost. The biofuel supply cost includes the production cost as well as the cost for transporting and distributing the produced biofuel.

In the scenarios without policy support (A scenarios), the resulting second generation biofuel share turned out to be too low to be analysable ( $<0.2 \%$ for all scenarios). The inclusion of either a $\mathrm{CO}_{2} \operatorname{cost}$ (B scenarios) or targeted biofuel support (C scenarios) led to significantly higher biofuel shares over all studied scenarios. Figure 6 shows the average biofuel supply cost in the B and C scenarios, in relation to the resulting share of second generation biofuels in the EU transport fuel mix.
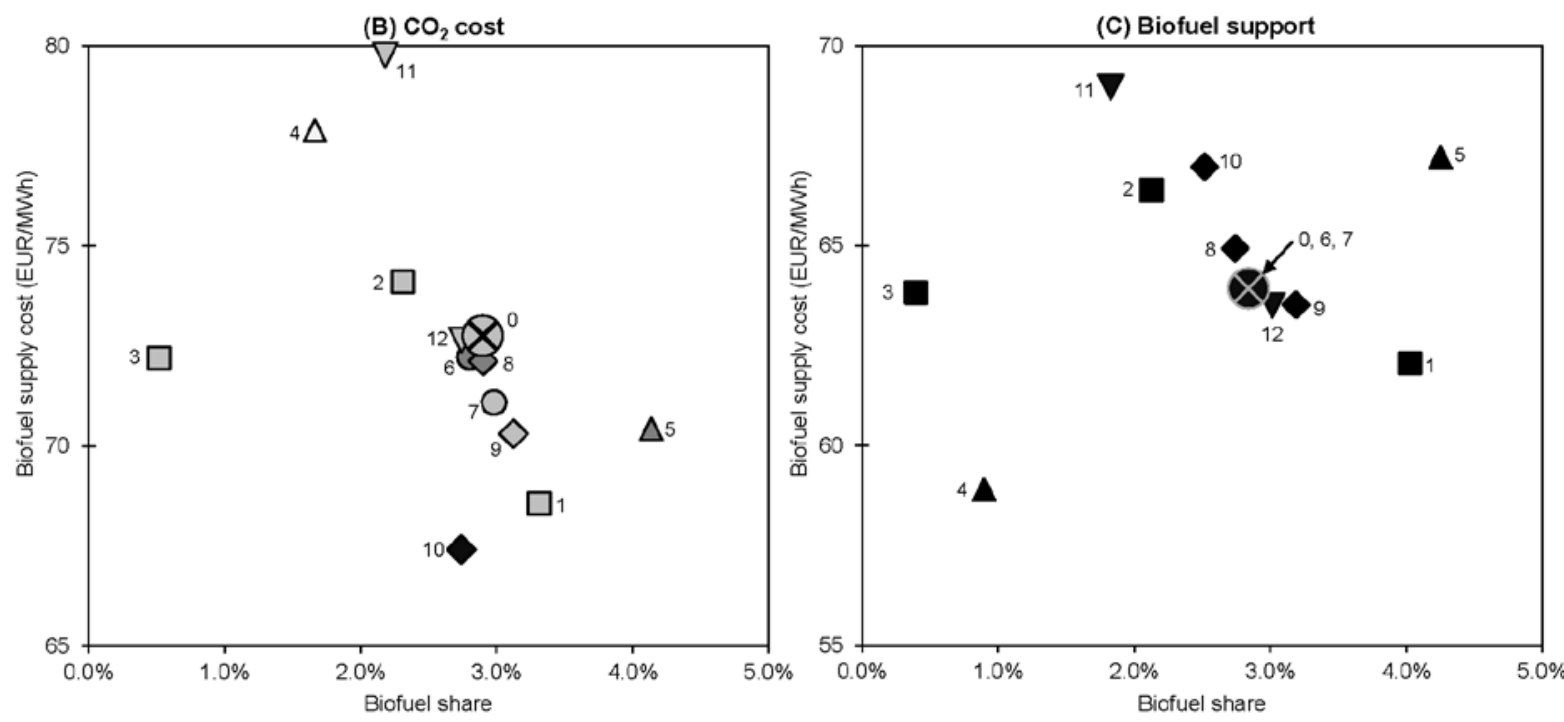

\begin{tabular}{|c|c|c|c|c|}
\hline Marker symbols & \multicolumn{2}{|c|}{ Marker colours } & \multicolumn{2}{|l|}{ Scenarios } \\
\hline (2) Base scenario $(0)$ & & Methanol share (\%) & 0. Base scenario & 7. Electricity price $+25 \%$ \\
\hline G Feedstock variations (1-3) & 0 & $\begin{array}{llll}25 & 50 & 75 & 100\end{array}$ & 1. Feedstock price $-25 \%$ & 8. Heat price $-25 \%$ \\
\hline$\Delta \quad$ Fuel price variations (4-5) & & & 2. Feedstock price $+25 \%$ & 9. Heat price $+25 \%$ \\
\hline - Electricity price variations $(6-7)$ & & & 3. Feedstock availability $-75 \%$ & 10. No heat demand \\
\hline$\diamond$ Heat variations $(8-10)$ & 100 & $75 \quad 50$ & 4. Fossil fuel price $-25 \%$ & 11. Investment cost $+25 \%$ \\
\hline$\nabla$ Plant cost variations $(11-12)$ & & Ethanol share (\%) & $\begin{array}{l}\text { 5. Fossil fuel price }+25 \% \\
6 \text {. Electricity price }-25 \%\end{array}$ & $\begin{array}{l}\text { 12. Inv, + O\&M costs harmonised for } \\
\text { all biofuel prod. technologies }\end{array}$ \\
\hline
\end{tabular}

Figure 6. Average biofuel supply cost (EUR/MWh) related to second generation biofuel share in the scenarios applying a $\mathrm{CO}_{2}$ cost (B scenarios) and the scenarios applying biofuel support (C scenarios). The shade of the markers indicates whether a scenario is dominated by methanol or ethanol plants. Note that different scaling of the $y$-axis is applied in the two graphs.

As mentioned in the introduction, around 3\% of the total EU transport energy demand should be second generation biofuels in 2020, in order to be able to meet the $10 \%$ target without significant interference with other goals. The results show that with current energy prices and adequate policy support, this goal can be met at a supply cost to consumers of approximately 65-73 EUR/MWh. This can be compared to average EU pump prices in 2009 of around $45 \mathrm{EUR} / \mathrm{MWh}$ without taxes, or around $100 \mathrm{EUR} / \mathrm{MWh}$ including taxes and duties. Without any policy support, the resulting biofuel share never reaches even a $1 \%$ share.

In the figure, the shade of the markers indicates whether a scenario is dominated by methanol plants (dark markers) or ethanol plants (light markers). The dominant type of plant influences both supply cost and biofuel share, with in general a lower biofuel share in ethanol-dominated scenarios, due to lower biomass-to-biofuel conversion efficiency. Ethanol generally becomes more prominent in 
scenarios with lower fuel price (scenario 4) and higher electricity and heat price (scenarios 7 and 9), due to the higher co-production of additional energy carriers.

The two studied policy instruments affect the biofuel production in different ways, which is reflected in the analysed scenarios. The inclusion of a $\mathrm{CO}_{2}$ cost (B scenarios) does not directly affect the cost of producing or supplying biofuel. Instead, it makes biofuel production competitive to fossil energy carriers due to displacement of $\mathrm{CO}_{2}$ emissions. For this reason, inclusion of a $\mathrm{CO}_{2}$ cost stimulates ethanol production, as the substituted $\mathrm{CO}_{2}$ emissions from the co-products are larger than from the biofuel (discussed in more detail in section 3.4). The inclusion of biofuel support, on the other hand (C scenarios), increases the competitiveness of biofuels due to an increased cost for the alternative (fossil transport fuels). This stimulates methanol production, due to a higher biomass-to-biofuel conversion efficiency.

The cost and availability of biomass feedstock (scenarios 1-3) has a large influence on both biofuel share and supply cost, in the B as well as the C scenarios. The fossil fuel price mainly affects the biofuel share, with a high fossil fuel price (scenario 5) resulting in a considerable increase in biofuel production. In the B scenarios this entails a shift towards more methanol and a lower biofuel supply cost, due to a higher total amount of produced biofuel. In the $\mathrm{C}$ scenarios there is no shift in technology choice, and a higher fossil fuel price allows for biofuel production to be competitive also at more high-cost locations, which instead gives a higher supply cost.

As could be expected, higher revenue for sold heat leads to lower supply costs, in particular in the scenarios including ethanol production (B scenarios), where the amount of co-produced heat is larger. The revenue for electricity affects the solution only in the B scenarios, since the methanol dominated C scenarios do not have an electricity surplus. The possibility to deliver heat to district heating networks affects both the total number of plants and the type of preferred biofuel production technology, shifting the production from ethanol to methanol when no heat delivery is possible (scenario 10). A higher capital cost (scenario 11) unsurprisingly increases the supply cost and decreases the biofuel share. Harmonisation of the investment and O\&M costs (scenario 12), does not affect the results to any significant extent.

With a $\mathrm{CO}_{2}$ cost applied, the biofuel share is relatively insensitive to changes in other parameters, with the exception of feedstock availability and transport fuel price. With biofuel support, the biofuel share is more sensitive to parameter variations, while the supply cost is less affected than when a $\mathrm{CO}_{2}$ cost is included. The parameters having the largest effect are feedstock price and availability, fossil fuel price and capital costs.

\subsection{Biofuel production plant locations}

In the 39 studied scenarios (A0-A12, B0-B12, C0-C12), the optimal number of production plants ranges from 0 to 87, with a second generation biofuel share for the EU spanning from 0 to over $4 \%$. Figure 7 shows the location of biofuel production plants in the two policy support base scenarios (B0 and $\mathrm{C} 0$ ), while Figure 8 shows the geographic distribution of the optimal plant locations, grouped by number of occurrences over all studied scenarios. All plants reached the maximum plant capacity of $100 \mathrm{t}_{\text {biomass }} / \mathrm{h}$. 


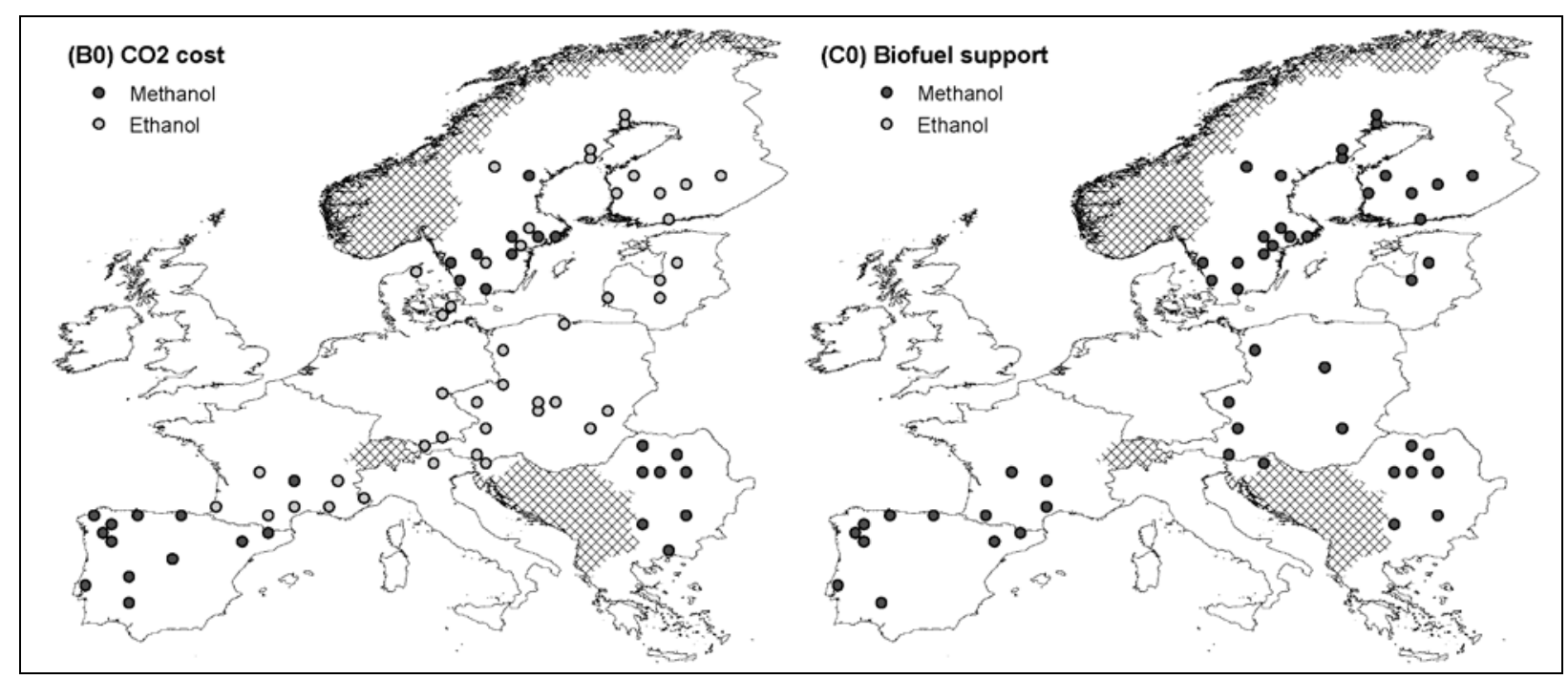

Figure 7. Plant locations in the two policy support base scenarios (B0 and $\mathrm{C} 0$ ).

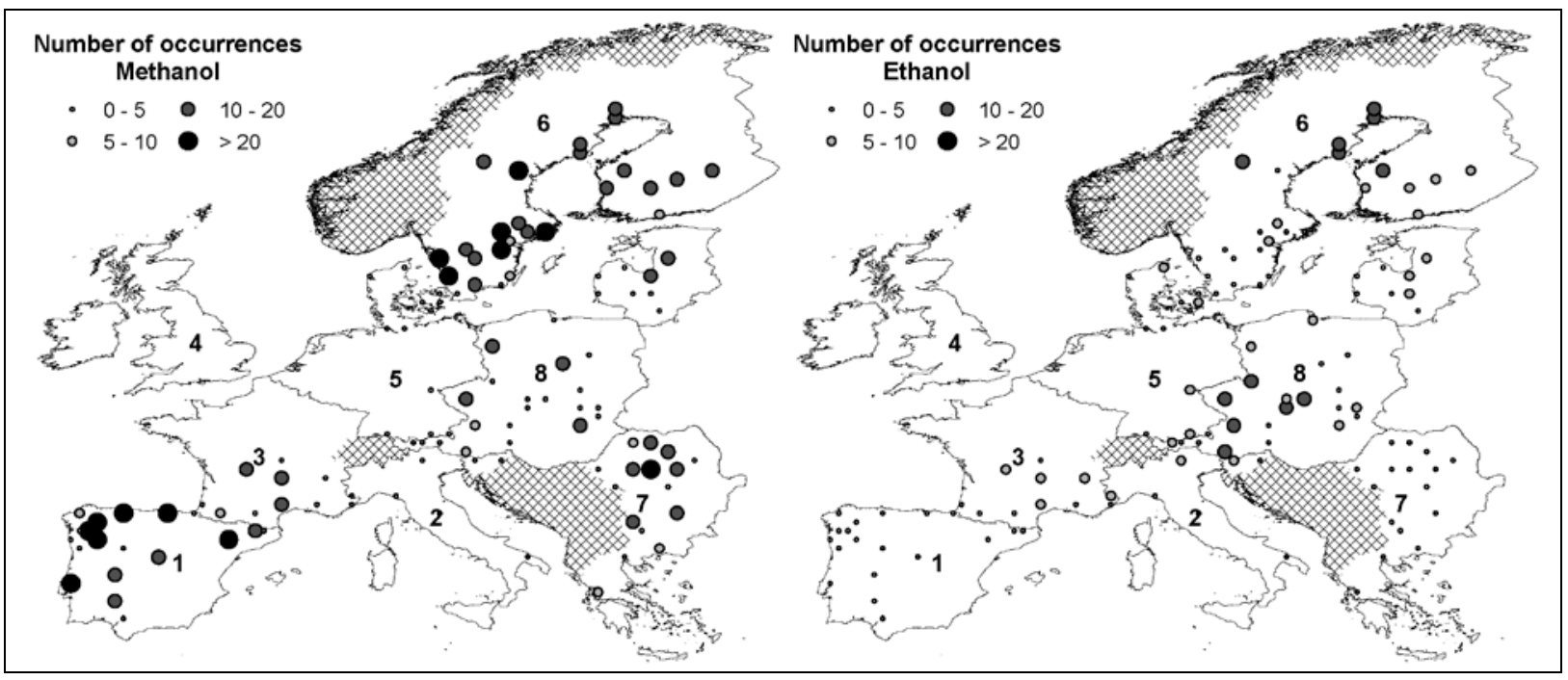

Figure 8. Number of plant occurrences for the studied biofuels over all scenarios.

In general, the plants are located close to where the biomass availability is high. This is especially pronounced for the northern parts of region 1 (Spain), region 6 (Sweden, Finland and the Baltic states) and for the southwest part of region 8 (Austria). While the locations of methanol plants are distributed over large areas of the EU, ethanol plants mainly occur in the northeast regions, where both the availability of biomass and the heat sink potential are good. Since the transport fuel demand is low in large parts of region 6 in particular, not all produced biofuel can be utilised in the production region. Instead biofuel is exported to other regions. Regions with high population densities and low availability of reasonably priced biomass feedstock have little or no production of their own. This includes region 2 (Italy), region 4 (UK and Ireland), and region 5 (Germany, Belgium, the Netherlands and Denmark). Those regions meet most or all biofuel demand with imported fuels, while region 6 acts as a net exporter in a large share of the studied scenarios.

Since the studied biofuel production technologies have a reasonably high co-production of heat, the optimal plant locations are typically located in populated areas. However, in reality not all of those locations are likely to be suitable for large-scale biofuel production, due to high land and biomass prices, as well as to biomass logistics issues. 
Figure 9 shows how much biofuel is produced and used in each region in the two policy support base scenarios. As can be seen, a significant part (> 35\%) of the total biofuel production in scenarios B0 and $\mathrm{C} 0$ originates in region 6 , while several of the other regions have considerably higher biofuel use than production (compare black diamonds to columns in the figure). Even though a substantial part of the total production in region 6 is exported to other regions, the biofuel share in the transport fuel mix (unfilled circles in the figure) is still large in region 6 compared to the other regions, as well as compared to the overall biofuel share in the EU of 3\%. The figure also shows that region 2, with very low in-region production, still reaches high biofuel shares. The reason is the high fossil fuel price in Italy compared to the price in for example region 4, where no biofuel is used.

For reference, the model is executed with the biofuel demand fixed to a mandatory $3 \%$ in each region (also included in Figure 9). As can be seen, the regional distribution of the biofuel production is virtually unchanged from scenario $\mathrm{C} 0$, indicating that this is indeed a cost optimal distribution of production plant locations. The used biofuel and the biofuel share, however, change substantially, with large amounts of biofuel being exported from regions 6 and 7, and, to a lesser extent, from region 1.

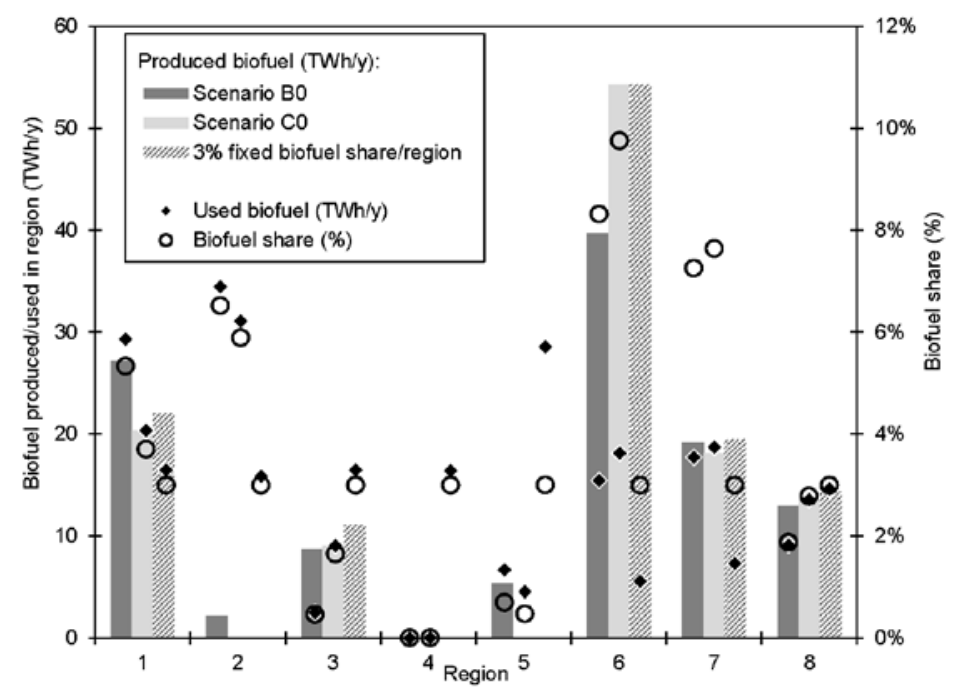

Figure 9. Produced (columns) and used (black diamonds) biofuel for each region in the two policy support base scenarios (B0 and C0). The circles indicate share of second generation biofuels in the transport fuel mix for each region.

\subsection{Biofuel share and $\mathrm{CO}_{2}$ emission reduction potential}

The reduction of fossil $\mathrm{CO}_{2}$ emissions is one of the main motivations behind policies and targets promoting a transition towards biofuels in the transport sector. In Figure 10, the potential $\mathrm{CO}_{2}$ emission reduction in the studied scenarios is plotted in relation to the corresponding biofuel share. Unsurprisingly, an increasing biofuel share entails an increasing emission reduction potential. This is more significant in scenarios where ethanol plants dominate, than in scenarios where methanol plants do. The reason is the high conversion efficiency to electricity and heat in ethanol plants, in combination with the in general significantly higher $\mathrm{CO}_{2}$ emission factors of displaced electricity and heat compared to displaced fossil transport fuels. Consequently, a considerable part of the reduced $\mathrm{CO}_{2}$ emissions in the ethanol-dominated scenarios can be attributed to the co-products. This indicates that if stationary biomass applications, such as biomass CHP, were included in the model, biofuels might not necessarily show as much benefit from a high $\mathrm{CO}_{2}$ cost as they do in this study. 


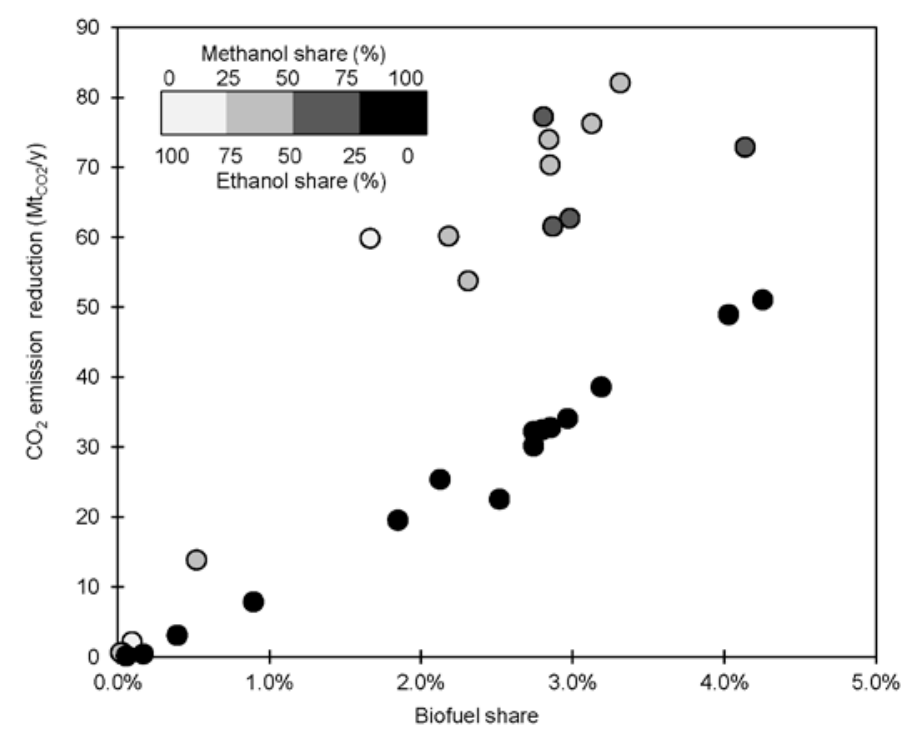

Figure 10. $\mathrm{CO}_{2}$ emission reduction potential $\left(\mathrm{Mt}_{\mathrm{CO} 2} / \mathrm{y}\right)$ related to biofuel share. The shade of the markers indicates whether a scenario is dominated by methanol or ethanol plants.

\section{$4 \quad$ Discussion and conclusions}

The aim of this paper has been to develop a biofuel production localisation model for the EU, and use it to perform investigations of how second generation biofuel production is affected by different parameters, in particular policy instruments and energy prices. Two policy instruments have been considered - a targeted biofuel support in the form of for example tax reduction, feed-in tariffs or green certificates, and a cost of emitting fossil $\mathrm{CO}_{2}$, in the form of for example a tax or tradable emission permits.

The results show that around 3\% of the total demand of energy for transport can be met by second generation biofuels at a supply cost to consumers of approximately 65-73 EUR/MWh, which can be compared to average EU pump prices in 2009 of around 45 EUR/MWh (without taxes). With energy prices comparable to today's prices, however, this demands considerable policy support, either in the form of biofuel production incentives at a level comparable to the tax exemption in place in many EU countries today (around $30 \mathrm{EUR} / \mathrm{MWh}$ ), or in the form of a cost of emitting $\mathrm{CO}_{2}$ of around $60 \mathrm{EUR} / \mathrm{t}_{\mathrm{CO} 2}$. The results also show that parameters having large effect on biofuel costs and production volumes are feedstock availability, fossil fuel price and capital costs.

Northern EU, with good feedstock availability and demand for co-produced heat, shows opportunities to become a key production region for second generation biofuels, with export to other parts of the EU. It can be concluded, however, that in order for all regions of the EU to reach high shares of second generation biofuels, strong incentives will be needed, as the biofuel distribution will otherwise be significantly higher in the production regions than in the import regions.

It can also be concluded that while forceful policies promoting biofuels may indeed lead to a high share of second generation biofuels in the EU fuel mix at a reasonable cost, this is not a certain path towards maximised $\mathrm{CO}_{2}$ emission mitigation. The two policy instruments included in this study are to some extent both in place in the EU today. The results from this study show a potential conflict of interest between different parts of the overall EU targets of increased use of renewable energy in transport, and decreased $\mathrm{CO}_{2}$ emissions. Since biomass is a limited resource, policies aiming at promoting its use need to be carefully designed in order not to counteract each other.

A final conclusion is that in order to reach the EU targets, more and improved interdisciplinary crosssectorial energy system studies will be needed. The model developed and used within this study, could come to constitute a key component for this kind of studies, which makes it highly relevant for policy makers. 


\section{Acknowledgements}

This work was carried out at IIASA as a part of the Young Scientists Summer Program (YSSP) 2010. The work has also been carried out under the auspices of the Energy Systems Programme, which is funded by the Swedish Energy Agency. The Swedish Research Council Formas and Ångpanneföreningen's Foundation for Research and Development, as well as the EC projects CCTame, Pashmina and Energeo, are gratefully acknowledged for their financial support.

\section{References}

[1] European Commission. 2020 by 2020: Europe’s climate change opportunity, COM(2008) 30 final. Brussels, Belgium; European Commission; 2008.

[2] European Commission. Biomass action plan, COM(2005) 628. 2005.

[3] Dir 2009/28/EC. Directive 2009/28/EC of the European Parliament and of the Council of 23 April 2009 on the promotion of the use of energy from renewable sources and amending and subsequently repealing Directives 2001/77/EC and 2003/30/EC.

[4] Dir 2003/30/EC. Directive 2003/30/EC of the European Parliament and of the Council of 8 May, 2003, on the promotion of the use of biofuels or other renewable fuels for transport.

[5] European Commission. EU energy and transport in figures. Statistical Pocketbook 2010. Luxembourg; 2010.

[6] EurObserv'ER. Biofuels Barometer. Systèmes Solaires - Le Journal des Energies Renouvelables; 2011.

[7] Wiesenthal T, Leduc G, Christidis P, Schade B, Pelkmans L, Govaerts L, et al. Biofuel support policies in Europe: Lessons learnt for the long way ahead. Renewable and Sustainable Energy Reviews 2009;13(4):789-800.

[8] European Commission. SEC(2009) 503 final. Accompanying document to the EC Communication "The Renewable Energy Progress Report" (COM(2009) 192). 2009.

[9] Fargione J, Hill J, Tilman D, Polasky S, Hawthorne P. Land clearing and the biofuel carbon debt. Science 2008;319(5867):1235-8.

[10] Searchinger T, Heimlich R, Houghton RA, Dong F, Elobeid A, Fabiosa J, et al. Use of U.S. croplands for biofuels increases greenhouse gases through emissions from land-use change. Science 2008;319(5867):1238-40.

[11] Al-Riffai P, Dimaranan B, Laborde D. Global Trade and Environmental Impact Study of the EU Biofuels Mandate. International Food Policy Institute (IFPRI) for the Directorate General for Trade of the European Commission; 2010.

[12] Fonseca MB, Burrell A, Gay H, Henseler M, Kavallari A, M'Barek R, et al. Impacts of the EU biofuel target on agricultural markets and land use: a comparative modelling assessment. In: Burrell A, (editor). European Commission, Joint Research Centre, Institute for Prospective Technological Studies; 2010.

[13] Faaij APC. Bio-energy in Europe: changing technology choices. Energy Policy 2006;34(3):32242.

[14] Dir 2004/8/EC. Directive 2004/8/EC of the European Parliament and of the Council of 11 February 2004 on the promotion of cogeneration based on a useful heat demand in the internal energy 
market and amending Directive 92/42/EEC on the promotion of the use of biofuels or other renewable fuels for transport.

[15] Börjesson M, Ahlgren EO. Biomass gasification in cost-optimized district heating systems-A regional modelling analysis. Energy Policy 2010;38(1):168-80.

[16] Wetterlund E, Söderström M. Biomass gasification in district heating systems - The effect of economic energy policies. Applied Energy 2010;87(9):2914-22.

[17] Schmidt J, Leduc S, Dotzauer E, Kindermann G, Schmid E. Cost-effective $\mathrm{CO}_{2}$ emission reduction through heat, power and biofuel production from woody biomass: A spatially explicit comparison of conversion technologies. Applied Energy 2010;87(7):2128-41.

[18] Steubing B, Zah R, Ludwig C. Life cycle assessment of SNG from wood for heating, electricity, and transportation. Biomass and Bioenergy 2011;35(7):2950-60.

[19] Fahlén E, Ahlgren EO. Assessment of integration of different biomass gasification alternatives in a district-heating system. Energy 2009;34(12):2184-95.

[20] Leduc S, Natarajan K, Dotzauer E, McCallum I, Obersteiner M. Optimizing biodiesel production in India. Applied Energy 2009;86(SUPPL. 1):S125-S31.

[21] Leduc S, Schmid E, Obersteiner M, Riahi K. Methanol production by gasification using a geographically explicit model. Biomass and Bioenergy 2009;33(5):745-51.

[22] Leduc S, Schwab D, Dotzauer E, Schmid E, Obersteiner M. Optimal location of wood gasification plants for methanol production with heat recovery. International Journal of Energy Research 2008;32(12):1080-91.

[23] Leduc S, Starfelt F, Dotzauer E, Kindermann G, McCallum I, Obersteiner M, et al. Optimal location of lignocellulosic ethanol refineries with polygeneration in Sweden. Energy 2010;35(6):270916.

[24] Leduc S. Development of an Optimization Model for the Location of Biofuel Production Plants [Doctoral Thesis]. Luleå: Luleå University of Technology, 2009.

[25] Wetterlund E. Optimal localisation of biofuel production on a European scale. IIASA Interim Report, IR-10-020. Laxenburg, Austria: International Institute for Applied Systems Analysis (IIASA); Available at: http://www.iiasa.ac.at/Admin/PUB/; 2010.

[26] McCarl BA, Meeraus A, Eijk Pvd, Bussieck M, Dirkse S, Steacy P. McCarl Expanded GAMS User Guide Version 22.9. GAMS Development Corporation; 2008.

[27] JRC. The global land cover map for the year 2000. GLC2000 database. In: Centre ECJR, (editor). Ispra, Italy; 2003.

[28] Cramer W, Kicklighter DW, Bondeau A, Moore Iii B, Churkina G, Nemry B, et al. Comparing global models of terrestrial net primary productivity (NPP): Overview and key results. Global Change Biology 1999;5(SUPPL. 1):1-15.

[29] Kindermann GE, McCallum I, Fritz S, Obersteiner M. A global forest growing stock, biomass and carbon map based on FAO statistics. Silva Fennica 2008;42(3):387-96.

[30] Swedish Energy Agency. Trädbränsle- och torvpriser, nr 2/2011 (Wood fuel and peat prices, in Swedish). Sveriges officiella statistik, statistiska meddelanden EN 0307 SM 1102. Eskilstuna: Swedish Energy Agency; 2011. 
[31] Olsson O, Vinterbäck J, Porsö C. EUBIONET III, WP3 - Wood fuel price statistics in Europe - D 3.1. Uppsala: Swedish University of Agricultural Sciences; 2010.

[32] Hamelinck CN, Faaij APC. Future prospects for production of methanol and hydrogen from biomass. Journal of Power Sources 2002;111(1):1-22.

[33] Wahlund B, Yan JY, Westermark M. Increasing biomass utilisation in energy systems: A comparative study of $\mathrm{CO}_{2}$ reduction and cost for different bioenergy processing options. Biomass and Bioenergy 2004;26(6):531-44.

[34] Barta Z, Reczey K, Zacchi G. Techno-economic evaluation of stillage treatment with anaerobic digestion in a softwood-to-ethanol process. Biotechnology for Biofuels 2010;3(21).

[35] Dornburg V, Faaij APC. Efficiency and economy of wood-fired biomass energy systems in relation to scale regarding heat and power generation using combustion and gasification technologies. Biomass and Bioenergy 2001;21(2):91-108.

[36] Sørensen ÅL. Economies of Scale in Biomass Gasification Systems. IIASA Interim Report, IR05-030. Laxenburg, Austria: International Institute for Applied Systems Analysis (IIASA); 2005.

[37] Remer DS, Chai LH. Design cost factors for scaling-up engineering equipment. Chemical Engineering Progress 1990;86(8):77-82.

[38] CEPCI. Chemical Engineering Plant Cost Index. Available at: www.che.com/pci; 2010.

[39] Börjesson P, Gustavsson L. Regional production and utilization of biomass in Sweden. Energy 1996;21(9):747-64.

[40] Edwards R, Larivé J-F, Mahieu V, Rouveirolles P. Well-to-wheels analysis of future automotive fuels and powertrains in the European context, version 2c. JRC, EUCAR and CONCAWE; 2007.

[41] European Commission. European Energy and Transport Trends to 2030 - update 2007. Luxembourg: European Commission, Directorate-General for Energy and Transport; 2008.

[42] Center for International Earth Science Information Network (CIESIN). Global Rural-Urban Mapping Project (GRUMP): Settlement Points. 2005.

[43] Werner S. Ecoheatcool 2005-2006, Work package 1 (The European heat market) and 4 (Possibilities with more district heating in Europe). Brussels, Belgium: Euroheat and Power; 2006.

[44] Egeskog A, Hansson J, Berndes G, Werner S. Co-generation of biofuels for transportation and heat for district heating systems - an assessment of the national possibilities in the EU. Energy Policy 2009;37(12):5260-72.

[45] Knutsson D, Sahlin J, Werner S, Ekvall T, Ahlgren EO. HEATSPOT - a simulation tool for national district heating analyses. Energy 2006;31(2-3):278-93.

[46] Gode J, Martinsson F, Hagberg L, Öman A, Höglund J, Palm D. Environmental facts 2011. Estimated emission factors for fuels, electricity, heat and transport in Sweden (Miljöfaktaboken 2011, in Swedish). report no. 1183. Stockholm: Värmeforsk; 2011.

[47] Dir 2003/54/EC. Directive 2003/54/EC of the European Parliament and of the Council of June 26, 2003, concerning common rules for the internal market in electricity and repealing Directive 96/92/EC. 
[48] Dir 2009/72/EC. Directive 2009/72/EC of the European Parliament and of the Council of 13 July 2009 concerning common rules for the internal market in electricity and repealing Directive 2003/54/EC.

[49] Axelsson E, Harvey S, Berntsson T. A tool for creating energy market scenarios for evaluation of investments in energy intensive industry. Energy 2009;34(12):2069-74.

[50] Wetterlund E, Pettersson K, Magnusson M. Implications of system expansion for the assessment of well-to-wheel $\mathrm{CO}_{2}$ emissions from biomass-based transportation. International Journal of Energy Research 2010;34(13):1136-54.

[51] European Commission. European Reference Life Cycle Database (ELCD) European Commission, Joint Research Centre; 2010.

[52] European Commission. Oil Bulletin. European Commission, Directorate-General for Energy; 2010.

[53] Eurostat. Eurostat - Energy statistics. European Commission; 2010.

[54] ICE Futures Europe. ICE-ECX European Emissions, Emissions Index (ECX EUA Futures); 2011. Available at: http://www.theice.com [September, 2011].

[55] Tol RSJ. The marginal damage costs of carbon dioxide emissions: an assessment of the uncertainties. Energy Policy 2005;33(16):2064-74.

[56] European Commission. ExternE - Externalities of Energy: Methodology 2005 Update. Luxembourg: Directorate-General for Research; 2005.

[57] Jung A, Dörrenberg P, Rauch A, Thöne M. Biofuels - at what cost? Government support for ethanol and biodiesel in the European Union. Geneva, Switzerland: The Global Subsidies Initiative of the International Institute for Sustainable Development; 2010. 


\section{Appendix A}

Table A.1. Country-specific input data. Abbreviations: DH = district heating, El. = electricity.

\begin{tabular}{|c|c|c|c|c|c|c|c|}
\hline \multirow[t]{2}{*}{ Country } & \multirow{2}{*}{$\begin{array}{l}\text { Population } \\
\text { (million }^{\text {people) }}\end{array}$} & \multicolumn{2}{|c|}{$\begin{array}{l}\text { Energy demand } \\
\text { (MWh/capita,y) }\end{array}$} & \multicolumn{3}{|c|}{$\begin{array}{c}\text { Energy prices } \\
\text { EUR/MWh }\end{array}$} & \multirow{2}{*}{$\begin{array}{c}\mathrm{CO}_{2} \text { emission } \\
\text { factors } \\
\mathrm{kg}_{\mathrm{CO} 2} / \mathrm{MWh} \\
\mathrm{DH}^{\mathrm{f}}\end{array}$} \\
\hline & & Transp. fuel $^{\mathrm{a}}$ & $\mathrm{DH}^{\mathrm{b}}$ & Transp. fuel $^{\mathrm{C}}$ & $\mathrm{DH}^{\mathrm{d}}$ & $\mathrm{El}^{\mathrm{e}}$ & \\
\hline Austria & 8.4 & 11 & 2.9 & 43 & 31 & 76 & 310 \\
\hline Belgium & 11 & 9.9 & 2.6 & 45 & 24 & 75 & 275 \\
\hline Bulgaria & 6.8 & 6.3 & 2.7 & 41 & 12 & 47 & 397 \\
\hline Czech Rep. & 9.9 & 9.6 & 5.9 & 46 & 21 & 88 & 398 \\
\hline Denmark & 5.5 & 9.4 & 5.1 & 49 & 36 & 69 & 413 \\
\hline Estonia & 1.2 & 8.8 & 5.8 & 43 & 12 & 40 & 354 \\
\hline Finland & 5.4 & 9.2 & 7.6 & 49 & 17 & 51 & 425 \\
\hline France & 64 & 8.6 & 1.8 & 43 & 24 & 49 & 259 \\
\hline Germany & 83 & 7.5 & 3.2 & 44 & 28 & 76 & 318 \\
\hline Greece & 11 & 8.1 & 0.46 & 50 & 18 & 60 & 309 \\
\hline Hungary & 9.7 & 6.1 & 4.0 & 47 & 19 & 91 & 287 \\
\hline Ireland & 4.8 & 12 & 1.2 & 45 & 14 & 82 & 277 \\
\hline Italy & 58 & 9.1 & 0.80 & 50 & 34 & 81 & 254 \\
\hline Latvia & 2.1 & 8.4 & 4.4 & 45 & 18 & 72 & 298 \\
\hline Lithuania & 3.2 & 6.6 & 3.8 & 45 & 19 & 68 & 303 \\
\hline Luxembourg & 0.5 & 61 & 3.9 & 46 & 24 & 65 & 276 \\
\hline Netherlands & 17 & 8.4 & 4.0 & 46 & 24 & 87 & 279 \\
\hline Poland & 37 & 5.7 & 4.0 & 44 & 16 & 69 & 422 \\
\hline Portugal & 11 & 7.8 & 0.58 & 49 & 14 & 58 & 322 \\
\hline Romania & 20 & 4.0 & 2.7 & 46 & 12 & 58 & 351 \\
\hline Slovakia & 5.3 & 5.2 & 4.5 & 45 & 18 & 97 & 304 \\
\hline Slovenia & 2.0 & 14 & 2.8 & 43 & 18 & 72 & 355 \\
\hline Spain & 46 & 10 & 0.52 & 48 & 14 & 68 & 255 \\
\hline Sweden & 9.6 & 9.9 & 1.7 & 42 & 28 & 49 & 394 \\
\hline UK & 63 & 7.8 & 1.6 & 41 & 14 & 90 & 261 \\
\hline
\end{tabular}

\footnotetext{
${ }^{\mathrm{a}}[41]$

b All existing fossil-fuel based district heating as well as replaced fossil fuels used directly for heating [43, 44]

${ }^{c}$ Average petrol and diesel pump prices (without taxes) in 2009 [52]

${ }^{\mathrm{d}}$ Estimated consumer price averages for 2003 [43], adjusted to EUR $_{2009}$. It is assumed possible to sell heat at $50 \%$ of the consumer price

${ }^{\mathrm{e}}$ Average end-user prices without taxes in 2009 [53]

f $[43,44,46]$
} 